\title{
ZS Research Square \\ The Social Risk Factors for Internet Addiction in College Undergraduate Students
}

Xia Lin

Sichuan University

Jingyan Gu

Seattle Pacific University

Wan-jun Guo

Sichuan University West China Hospital

Ya-jing Meng

Sichuan University West China Hospital

Hui-yao Wang

Sichuan University West China Hospital

Xiao-jing Li

Sichuan University West China Hospital

Wei Deng

Sichuan University West China Hospital

Lian-sheng Zhao

Sichuan University West China Hospital

Xiao-hong Ma

Sichuan University West China Hospital

Ming-li Li

Sichuan University West China Hospital

Ting Chen

Sichuan University West China Hospital

Andy S.K. Cheng

Hong Kong Polytechnic University

Tao Li ( $\square$ litaohx@scu.edu.cn )

Sichuan University https://orcid.org/0000-0003-3831-901X

Research article

Keywords: occupational, addictive behaviours, smoking, biopsychosocial

Posted Date: June 29th, 2020

DOI: https://doi.org/10.21203/rs.3.rs-33645/v1

License: (c) (i) This work is licensed under a Creative Commons Attribution 4.0 International License. Read Full License 


\section{Abstract}

Objective: The current study aims to explore precipitating and risk factors for internet addiction (IA) in university undergraduate students, and to provide evidence for interventions and the early prevention of IA in this population.

Method: Four thousand eight hundred and fifty-eight college sophomores completed an online survey on their internet use-related behaviours and social risk factors.

Result: Compared to female students (5.4\%), more male students (8.3\%) were in the moderate and severe IA groups. Male and female students tend to engage in different types of online entertainment. There are some shared and some different precipitating factors for internet use and risk factors for IA between the different gender groups.

Conclusion: By understanding the differences and similarities in risk factors for IA in both gender groups of the university undergraduate students, interventions can be more precisely designed to target specific behaviours in this populations.

\section{Background}

The internet use has grown exponentially during the past two decades. The development of the internet has brought convenience but also problems such as internet addiction (IA). Young (1998) defined IA as losing control over the time spent on the internet [1]. IA could potentially impair academic and occupational function as well as family life (Gao et al., 2010; Young, 1999).

Although there have been few worldwide studies on the prevalence rate of IA, studies conducted in different geographic regions suggest that it is a severe problem shared by many countries (the China Youth Internet Association, 2005; Goel et al, 2013; Greenfield, 1999). Furthermore, IA is associated with an increased rate of mental health problems. People with heavy IA, such as pathological heavy online game consumers, are likely to develop psychiatric disorders such as depression, social anxiety, and somatic symptoms (Wei et al., 2012).

The use of internet-based entertainment differs by gender and geographic region. In the United States, male internet users spend more time on pornography, and females usually spend time on online shopping (Young, 2013). In Europe, male internet users usually play single-player online games, while females spend most of their time on social media (Durkee et al., 2012). In Korea, $56.3 \%$ of males play online multiplayer games (Ha and Hwang, 2014). In Hong Kong, $30 \%$ of participants play online games (Wang et al., 2015). Similar to other addictive behaviours, people engage in online entertainment for different reasons. Shiffman and Rathbun (2011) found that people use smoking as a way to cope with negative affect [2]. IA has a clinical presentation similar to that of substance abuse and behavioural abuse, such as withdrawal symptoms, tolerance, and craving [3]. It is worth noting the difference between males and females in addictive behaviours. For example, women were more likely than men to use smoking to cope with negative affect, and a more recent study suggested that men are more likely to report somatic symptoms such as "ill, in pain, or uncomfortable" as triggers for using drugs (Kennedy et al, 2012).

Previous studies suggested that the severity of IA is positively correlated with the amount of time individuals spend on the internet (Rooij et al; Schoenmakers et al, 2010)[4]. However, currently, as technology use skyrockets, internet-based entertainment has become more accessible through smartphones, tablets, and other portable gaming devices (e.g., Nintendo Switch). Consequently, it is more difficult to assess the amount of time and the frequency of use in the traditional manner [5, 6]. In a more recent study, Li and colleagues (2015) found that sustained time spent on online entertainment tends to increase as IA severity increases [7]. The duration of sustained online entertainment for each episode of internet use might be a better indicator to measure the amount of time of internet use.

Existing studies on risk factors for IA were conducted under the biopsychosocial model. Under this model, the family environment was considered one of the most important social factors. Single-parent, frequent migration, left-behind by parents during childhood, and deceased parents were the most common risk factors (Guo et al; Chen et al, 2012). Boys who experience negative life events are more susceptible to IA [8]. In addition to the family environment, interpersonal interaction with peers has also been studied. As a platform for sharing similar activities, the internet is a place where adolescents socialize with each other. As a result, the influence of friends could exacerbate adolescents' dependence on the internet $[9,10]$. 
Previous studies have suggested that biological factors, social environment factors (e.g. family, friends, etc.), and other psychological conditions (e.g., depression and social anxiety) together impact individuals' internet use behaviour [11]. Positive emotions such as happiness, relaxation, confidence, and the sense of achievement that people receive from online activities could serve as moderators that exacerbate IA [12]. The findings are mixed on the effect of socioeconomic status (SES) and geographic location on IA. Family SES was found to be a predictor of IA. Specifically, children from higher SES families were more vulnerable to IA [13-15]. Parents' unemployment status and low education levels were also found to be associated with a higher risk of IA (Petry et al, 2014; American Society of Addiction Medicine, 2015). However, findings are inconsistent, and other studies suggested that parents' education level and family socioeconomic status had no impact on children's IA (Ghamari et al, 2011; Tang et al, 2014).

The current study aims to explore social risk factors for IA in college undergraduate students and to provide evidence for interventions and early prevention that target this specific population.

\section{Methods}

\subsection{Participants}

The investigation was carried out at a comprehensive university in mainland China. All sophomores $(9,367)$ were invited to complete a questionnaire online in November 2013. A total of 4,858 (51.86\%) responded and completed the survey.

\subsection{Measurements}

\subsubsection{Demographics}

The demographics collected in this self-made questionnaire included gender, age of participants, and social risk factors below in this survey.

The social risk factors included number of relocations, childhood trauma experience, whether father and/or mother deceased, infatuation with the internet before college, similar online activities in roommates, a romantic relationship, and unpleasant events on campus. They were defined as follows:

\section{Number of relocations}

Refers to the number of times the family's permanent residence was relocated. For the convenience of statistical analysis, those who had no relocation experience were assigned a value of 1, 1 relocation experience was assigned a value of 2, 2 relocation experiences were assigned a value of 3 , and 3 or more relocation experiences were assigned a value of 4 .

\section{Childhood trauma experience}

In this study, childhood trauma experience covers neglect and physical abuse before the age of 16 . The Childhood Trauma Questionnaire has been used to evaluate childhood traumatic experience and verified as having good reliability and validity [16, 17].

\section{Father and/or mother deceased}

Whether parents are deceased.

\section{Infatuation with the internet before college}

This item was self-reported; infatuation refers to an unreasonable passion for engaging in online activities.

\section{Similar online activities in roommates}

whether roommates share similar online activities 
With a romantic relationship

whether the participant was experiencing a romantic relationship or other relationships.

\section{Unpleasant events on campus}

Frequency of suffering unpleasant events after entering the university.

\subsubsection{Internet use behaviours}

We recorded the types of online entertainment activities (playing games, browsing information, chatting/posting comments, watching movies/TV series), the duration of sustained online entertainment (sustained engagement with online entertainment in hours for each internet use) and potential triggers for online entertainment activity, including boredom (Nalwa and Anand 2003, Gur, Yurt et al. 2015), loneliness/depression/escape (Engelberg and Sjoberg 2004, Zanetta Dauriat, Zermatten et al. 2011, Yen, Chou et al. 2014).

Young's Internet Addiction Test (IAT) revised edition by Young (2011), a 20-item self-evaluation scale including 6 levels $(0=$ not applicable, 1 = almost never, 2 = occasionally, 3 = sometimes, 4 = often, and 5 = almost), was used in the present study. An IAT score of 50 is commonly considered the cut-off score for IA, which means that individuals who scored 50 or higher were considered to have IA, and those who scored lower than 50 were considered being without IA [18, 19]. The total IAT score can be categorized into four classes of severity (normal: 0 to 30; mild: 31-49; moderate: 50-79; severe: 80-100) [20]. Young's IAT (2011) has been translated into different languages and has been verified to have good reliability and validity [21, 22]. The Chinese version was adopted for the present study (Cronbach's alpha: 0.9085) [23].

\subsection{Statistical analysis}

The participants were separated into three groups (normal group: 0-30, mild IA group: 31-49, and moderate and severe IA group: 50-100) based on the scores using the latest revision of the IAT (Young, 2011). SPSS19 was used for data analysis. Two-sample t-tests, chi-squared tests and analysis of variance (ANOVA) were used for continuous variables and categorical variables as appropriate. Multiple logistic regression analysis was applied to predict the risk of mild IA and moderate and severe IA. The statistical significance level was set as $p<.05$ (two-tailed). The Bonferroni correction and the corrected $p$-value were used to adjust the $p$-value while conducting the Chi-square analysis.

\section{Results}

\subsection{Demographics}

A total of 4,858 (51.86\%) sophomores participated in the cross-sectional study. Among these volunteers, $48.93 \%(2,377)$ were males and $51.07 \%(2,481)$ were females. The mean age was $19.58, S D=0.87$.

\subsection{Prevalence of IA and IAT mean scores}

The Cronbach's alpha coefficient and Guttman split-half coefficient of IAT were 0.915 and 0.845 , respectively, in the present study.

The prevalence of IA in total was 6.81\% (331/4858). The IA rate was 8.3\% in males (197/2377) and 5.4\% in females (134/2481). A higher IA rate in male participants $\left(x^{2}=23.115, p<0.001\right)$ was found in the current study among the 4,858 respondents. Furthermore, there were significant differences in the mean IAT score between the three IA severity groups $(F=4.344, p<0.001)$ (Table 1). 
Table 1

IA severity group's IAT mean scores and rate by gender

\begin{tabular}{|c|c|c|c|c|c|c|c|c|c|c|c|c|}
\hline \multirow{3}{*}{$\begin{array}{l}\text { IA } \\
\text { Severity }\end{array}$} & \multicolumn{4}{|l|}{ Rate } & \multirow[b]{3}{*}{$x^{2}$} & \multirow[b]{3}{*}{$\begin{array}{l}\mathrm{p}- \\
\text { value }\end{array}$} & \multicolumn{4}{|c|}{ IAT scores } & \multirow[b]{3}{*}{$F$} & \multirow[b]{3}{*}{$\begin{array}{l}\mathrm{p}- \\
\text { value }\end{array}$} \\
\hline & \multicolumn{2}{|l|}{ Male } & \multicolumn{2}{|c|}{ Female } & & & \multicolumn{2}{|l|}{ Male } & \multicolumn{2}{|c|}{ Female } & & \\
\hline & $\mathrm{n}$ & $\%$ & $n$ & $\%$ & & & $M$ & SD & $M$ & SD & & \\
\hline $\begin{array}{l}\text { The } \\
\text { normal } \\
\text { group }\end{array}$ & 1272 & 53.5 & 1461 & 58.9 & 23.115 & $\begin{array}{l}<.001 \\
0.00\end{array}$ & 23.66 & 4.197 & 24.09 & 4.080 & 4.344 & $<.001$ \\
\hline $\begin{array}{l}\text { The mild } \\
\text { IA group }\end{array}$ & 908 & 38.2 & 886 & 35.7 & & & 37.89 & 4.794 & 37.48 & 4.978 & & \\
\hline $\begin{array}{l}\text { The } \\
\text { moderate } \\
\text { and } \\
\text { severe IA } \\
\text { group }\end{array}$ & 197 & 8.3 & 134 & 5.4 & & & 59.91 & 8.962 & 58.15 & 9.382 & & \\
\hline Total & 2377 & 100.0 & 2481 & 100.0 & & & 32.1 & 11.829 & 30.71 & 10.304 & & \\
\hline
\end{tabular}

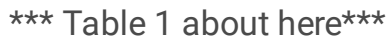

\subsection{Online entertainment activities, triggers, and duration of sustained online entertainment}

The duration of sustained online entertainment in the moderate and severe IA groups (approximately 5 hours) was significantly higher than that in the normal group (approximately 2 hours) for both males and females.

Online gaming is the main online entertainment activity among male students in the moderate and severe IA groups (55.8\%), whereas only $27 \%$ of male students in the normal group play online games.

The main trigger of online entertainment was boredom (male $>60 \%$, female $>70 \%$ ); however, negative affect was the most prevalent trigger of online entertainment activities in the moderate and severe IA groups (male $18.2 \%$, female $12.7 \%, p<0.001$ ).

There is no statistically significant difference between the two gender groups in the duration of sustained online entertainment (males $2.72 \pm 3.234$, females $2.58 \pm 2.983 ; t=1.527, p=0.527$ ). Compared to the normal group, the moderate and severe groups significantly differed in online entertainment activities, triggers, and duration of sustained online entertainment $(p<0.001)$.

(Table 2). 
Table 2

Sustained online entertainment duration, online entertainment activities and triggers in the moderate and severe IA groups compared with the normal group

\begin{tabular}{|c|c|c|c|c|c|c|c|c|}
\hline & Male & & & & Female & & & \\
\hline & $\begin{array}{l}\text { Normal } \\
\text { group }\end{array}$ & $\begin{array}{l}\text { The } \\
\text { moderate } \\
\text { and severe } \\
\text { group }\end{array}$ & $x^{2} / t$ & $\begin{array}{l}\mathrm{P} \text { - } \\
\text { value }\end{array}$ & $\begin{array}{l}\text { Normal } \\
\text { group }\end{array}$ & $\begin{array}{l}\text { The } \\
\text { moderate } \\
\text { and } \\
\text { severe } \\
\text { group }\end{array}$ & $x^{2} / t$ & $\begin{array}{l}\mathrm{P} \text { - } \\
\text { value }\end{array}$ \\
\hline & $n=1272$ & $n=197$ & & & $n=1461$ & $n=134$ & & \\
\hline & $\begin{array}{l}\mathrm{N}(\%) / \mathrm{M} \pm \\
\mathrm{SD}\end{array}$ & $\begin{array}{l}\mathrm{N}(\%) / \mathrm{M} \pm \\
\mathrm{SD}\end{array}$ & & & $\begin{array}{l}\mathrm{N}(\%) / \mathrm{M} \pm \\
\mathrm{SD}\end{array}$ & $\begin{array}{l}\mathrm{N}(\%) / \mathrm{M} \\
\pm \mathrm{SD}\end{array}$ & & \\
\hline $\begin{array}{l}\text { The sustained online } \\
\text { entertainment duration } \\
\text { (hours/every time) }\end{array}$ & $\begin{array}{l}2.14 \pm \\
2.174\end{array}$ & $\begin{array}{l}4.94 \pm \\
7.725\end{array}$ & -5.043 & $<.001$ & $\begin{array}{l}2.20 \pm \\
2.140\end{array}$ & $\begin{array}{l}4.76 \pm \\
9.434\end{array}$ & -3.110 & 0.002 \\
\hline Online entertainment activities & & & 78.397 & $<0.001$ & & & 27.115 & $\begin{array}{l}< \\
0.001\end{array}$ \\
\hline Playing games & $343(27.0)$ & $110(55.8)$ & & & $30(2.1)$ & $8(6.0)$ & & \\
\hline Browsing information & $223(17.5)$ & $18(9.1)$ & & & $170(11.6)$ & $9(6.7)$ & & \\
\hline Chatting/post bar & $147(11.6)$ & $28(14.2)$ & & & $213(14.6)$ & $23(17.2)$ & & \\
\hline Watching movies/TV series & $478(37.6)$ & $31(15.7)$ & & & $923(63.2)$ & $69(51.5)$ & & \\
\hline Others & $81(6.4)$ & $10(5.1)$ & & & $125(8.6)$ & $25(18.7)$ & & \\
\hline \multicolumn{3}{|c|}{ Online entertainment activity triggers } & 54.600 & $\dot{0} 001$ & & & 48.506 & $\begin{array}{l}<.001 \\
0.001\end{array}$ \\
\hline Boring & $864(67.9)$ & $125(63.5)$ & & & $1118(76.5)$ & $98(73.1)$ & & \\
\hline Lonely/depressed/escaping & $98(7.7)$ & $46(23.4)$ & & & $87(6.0)$ & $28(20.9)$ & & \\
\hline Friends'invitation & 193(15.2) & $21(10.7)$ & & & $76(5.2)$ & $1(0.7)$ & & \\
\hline Others & $117(9.2)$ & $5(2.5)$ & & & $180(12.3)$ & $7(5.2)$ & & \\
\hline
\end{tabular}

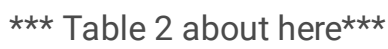

\subsection{Social environmental risk factors for Internet addiction}

The average number of relocations was $1.92 \pm 1.046$. The average score on childhood trauma experiences was $1.01 \pm 1.973$. A total of $7.5 \%$ of respondents (366/4800) had a father and/or mother deceased, and $12.5 \%$ of respondents $(607 / 4857)$ had been infatuated with the internet prior to college. A total of $72.1 \%$ of students (3504/4858) had roommates with similar online activities; $77.6 \%$ of students (3768/4858) did not have a romantic relationship; and $9.4 \%(456 / 4858)$ suffered unpleasant events on campus.

Students in the moderate and severe IA groups were more likely to report childhood trauma, being infatuated with internet entertainment before college, not in a romantic relationship, and suffering unpleasant events on campus $(p<0.05)$. Males in the moderate and severe IA groups were more likely to report relocation and father and/or mother deceased.

Additionally, more than $70 \%$ of male and female students reported that their roommates engaged in similar online entertainment activities, but the difference between the moderate and severe IA group and the normal group was only marginally significant ( $p$ $=.051)($ Table 3). 
Table 3

Migration in times, Childhood trauma experiences, parents, infatuating with the internet before college,roommates, with a romantic relationship, unpleasant events on campus between the moderate and severe group and normal group

\begin{tabular}{|c|c|c|c|c|c|c|c|c|}
\hline \multirow[b]{2}{*}{ Social factors } & \multicolumn{4}{|l|}{ Male } & \multicolumn{4}{|l|}{ Female } \\
\hline & $\begin{array}{l}\text { The } \\
\text { Normal } \\
\text { group }\end{array}$ & $\begin{array}{l}\text { The moderate } \\
\text { and severe IA } \\
\text { group }\end{array}$ & $t / x^{2}$ & $\begin{array}{l}\mathrm{p}- \\
\text { value }\end{array}$ & $\begin{array}{l}\text { The } \\
\text { Normal } \\
\text { group }\end{array}$ & $\begin{array}{l}\text { The moderate } \\
\text { and severe IA } \\
\text { group }\end{array}$ & $t / x^{2}$ & $\begin{array}{l}\mathrm{p}- \\
\text { value }\end{array}$ \\
\hline & $n=1272$ & $\mathrm{n}=197$ & & & $n=1461$ & $n=134$ & & \\
\hline & $\begin{array}{l}\mathrm{N}(\%) / \mathrm{M} \pm \\
\mathrm{SD}\end{array}$ & $N(\%) / M \pm S D$ & & & $\begin{array}{l}\mathrm{N}(\%) / \mathrm{M} \pm \\
\mathrm{SD}\end{array}$ & $N(\%) / M \pm S D$ & & \\
\hline $\begin{array}{l}\text { Migration in } \\
\text { times }\end{array}$ & $\begin{array}{l}1.826 \pm \\
1.151\end{array}$ & $2.26 \pm 1.505$ & -3.864 & $\dot{0} 0.001$ & $\begin{array}{l}1.97 \pm \\
1.150\end{array}$ & $2.04 \pm 1.300$ & -.681 & 0.496 \\
\hline $\begin{array}{l}\text { Childhood } \\
\text { trauma } \\
\text { experiences }\end{array}$ & $\begin{array}{l}7.06 \pm \\
2.439\end{array}$ & $7.88 \pm 2.533$ & -4.484 & $\dot{0} 001$ & $\begin{array}{l}6.64 \pm \\
1.527\end{array}$ & $7.20 \pm 1.679$ & -3.386 & 0.001 \\
\hline \multicolumn{3}{|c|}{$\begin{array}{l}\text { Father and/or mother } \\
\text { deceased }\end{array}$} & 13.387 & $\dot{0} 001$ & & & 3.783 & 0.052 \\
\hline No & 1174(93.5) & $166(86.0)$ & & & 1357(93.8) & 118(89.4) & & \\
\hline Yes & $82(6.5)$ & $27(14.0)$ & & & $90(6.2)$ & 14(10.6) & & \\
\hline \multicolumn{3}{|c|}{$\begin{array}{l}\text { Infatuating with the internet } \\
\text { before college }\end{array}$} & 152.356 & $<.001$ & & & 148.884 & $\dot{0} 001$ \\
\hline no & 1169(91.9) & $120(60.9)$ & & & 1409(96.4) & $95(70.9)$ & & \\
\hline yes & 103(8.1) & 77(39.1) & & & $52(3.6)$ & $39(29.1)$ & & \\
\hline \multicolumn{3}{|c|}{$\begin{array}{l}\text { Similar online activities in } \\
\text { roommates }\end{array}$} & 3.795 & 0.051 & & & 0.009 & 0.924 \\
\hline no & $404(31.8)$ & $49(24.9)$ & & & $420(28.7)$ & $38(28.4)$ & & \\
\hline yes & $868(68.2)$ & 148(75.1) & & & 1041(71.3) & $96(71.6)$ & & \\
\hline \multicolumn{3}{|c|}{ with a romantic relationship } & 5.563 & 0.018 & & & 6.780 & 0.009 \\
\hline no & $969(76.2)$ & 165(83.8) & & & 1096(75.0) & 114(85.1) & & \\
\hline others & $303(23.8)$ & $32(16.2)$ & & & $365(25.0)$ & $20(14.9)$ & & \\
\hline \multicolumn{3}{|c|}{ Unpleasant events in campus } & 147.518 & $\dot{0} 001$ & & & 111.463 & $\dot{0.001}$ \\
\hline rarely & $543(42.7)$ & $33(16.8)$ & & & $515(35.2)$ & $14(10.4)$ & & \\
\hline occasionally & $396(31.1)$ & $31(15.7)$ & & & $579(39.6)$ & $38(28.4)$ & & \\
\hline sometimes & $231(18.2)$ & 75(38.1) & & & $292(20.0)$ & $49(36.6)$ & & \\
\hline plenty & 102(8.0) & $58(29.4)$ & & & $75(5.1)$ & $33(24.6)$ & & \\
\hline
\end{tabular}

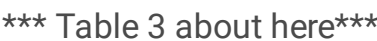 \\ 3.5 Multiple logistic regression analysis of gender interaction risk factors for IA}


The above 7 influencing factors were entered as variables using stepwise analysis, and an intergroup multiple logistic regression of IA degree was conducted with gender interaction. Risk factors for mild, moderate and severe IA were analysed (the normal group was taken as the reference variable). The model has an acceptable goodness of fit $\left(x^{2}=6013.952, p<0.001\right)$.

Infatuation with the internet before college and unpleasant events on campus were common risk factors for mild and moderate IA in both gender groups (all $p<0.001$ ). In particular, infatuation with the internet before college was the strongest predictor of moderate and severe IA (male: OR = 5.739, 95\% Cl: 3.862-8.529; female: OR = 12.239, 95\% Cl: 7.523-19.911).

Roommates engaging in similar online activities displayed a significant effect on male students' IA (mild IA group, $p<0.001,0 R$ $=1.535,95 \%$ Cl: 1.249-1.886; moderate and severe IA group, $p=0.002, O R=1.829,95 \%$ Cl: 1.240-2.698). In contrast, female students addicted to internet entertainment activities were influenced by the absence of romantic relationships (mild IA group, $p$ $=0.019, \mathrm{OR}=0.768,95 \% \mathrm{Cl}: 0.616-0.958 ;$ moderate and severe IA group, $\mathrm{p}=0.006, \mathrm{OR}=0.479,95 \% \mathrm{Cl}$ : 0.284-0.809) (Table 4). 
Table 4

Multivariate logistic regression analysis of gender interaction risk factors of Internet addiction

\begin{tabular}{|c|c|c|c|c|c|c|c|c|c|c|c|}
\hline \multicolumn{2}{|c|}{$\begin{array}{l}\text { Gender interaction Risk } \\
\text { factors }\end{array}$} & \multicolumn{5}{|c|}{ The mild IA group(IAT: 31-49 points) } & \multicolumn{5}{|c|}{$\begin{array}{l}\text { The moderate and severe IA group(IAT: } 50 \text { - } \\
100 \text { points) }\end{array}$} \\
\hline & & \multirow[t]{2}{*}{ B } & \multirow[t]{2}{*}{$\begin{array}{l}\mathrm{p}- \\
\text { value }\end{array}$} & \multirow[t]{2}{*}{ OR } & \multicolumn{2}{|c|}{$\begin{array}{l}95 \% \\
\text { confidence } \\
\text { interval }\end{array}$} & \multirow[t]{2}{*}{ B } & \multirow[t]{2}{*}{$\begin{array}{l}\mathrm{p}- \\
\text { value }\end{array}$} & \multirow[t]{2}{*}{ OR } & \multicolumn{2}{|c|}{$\begin{array}{l}95 \% \text { confidence } \\
\text { interval }\end{array}$} \\
\hline & & & & & low & high & & & & low & high \\
\hline & Intercept & -3.955 & 0.000 & & & & -8.261 & 0.000 & & & \\
\hline \multirow[t]{7}{*}{ Male } & $\begin{array}{l}\text { Father and/or } \\
\text { mother deceased }\end{array}$ & 0.350 & 0.033 & 1.420 & 1.029 & 1.958 & 0.497 & 0.061 & 1.644 & 0.978 & 2.765 \\
\hline & $\begin{array}{l}\text { Infatuating with } \\
\text { network before } \\
\text { college }\end{array}$ & 1.159 & $<0.001$ & 3.186 & 2.440 & 4.158 & 1.747 & 0.000 & 5.739 & 3.862 & 8.529 \\
\hline & $\begin{array}{l}\text { Unpleasant events } \\
\text { on campus }\end{array}$ & 0.276 & $<0.001$ & 1.318 & 1.187 & 1.463 & 0.547 & 0.000 & 1.728 & 1.432 & 2.087 \\
\hline & $\begin{array}{l}\text { with a romantic } \\
\text { relationship }\end{array}$ & -0.204 & 0.081 & 0.815 & 0.648 & 1.026 & -0.417 & 0.071 & 0.659 & 0.419 & 1.036 \\
\hline & $\begin{array}{l}\text { Similar online } \\
\text { activities in } \\
\text { roommates }\end{array}$ & 0.428 & $<001$ & 1.535 & 1.249 & 1.886 & 0.604 & 0.002 & 1.829 & 1.240 & 2.698 \\
\hline & $\begin{array}{l}\text { Childhood trauma } \\
\text { experiences }\end{array}$ & -0.013 & 0.519 & 0.987 & 0.947 & 1.028 & 0.040 & 0.190 & 1.041 & 0.980 & 1.106 \\
\hline & Migration in times & 0.105 & 0.026 & 1.110 & 1.013 & 1.218 & 0.147 & 0.071 & 1.158 & 0.988 & 1.358 \\
\hline \multirow[t]{7}{*}{ Female } & $\begin{array}{l}\text { Father and/or } \\
\text { mother deceased }\end{array}$ & 0.076 & 0.665 & 1.079 & 0.766 & 1.520 & 0.667 & 0.033 & 1.948 & 1.056 & 3.592 \\
\hline & $\begin{array}{l}\text { Infatuating with } \\
\text { network before } \\
\text { college }\end{array}$ & 1.421 & $<001$ & 4.143 & 2.937 & 5.844 & 2.505 & $<001$ & 12.239 & 7.523 & 19.911 \\
\hline & $\begin{array}{l}\text { Unpleasant events } \\
\text { in campus }\end{array}$ & 0.264 & $<0.001$ & 1.302 & 1.162 & 1.458 & 0.489 & $<.001$ & 1.630 & 1.294 & 2.053 \\
\hline & $\begin{array}{l}\text { with a romantic } \\
\text { relationship }\end{array}$ & -0.264 & 0.019 & 0.768 & 0.616 & 0.958 & -0.736 & 0.006 & 0.479 & 0.284 & 0.809 \\
\hline & $\begin{array}{l}\text { Similar online } \\
\text { activities in } \\
\text { roommates }\end{array}$ & 0.335 & 0.001 & 1.398 & 1.143 & 1.708 & 0.388 & 0.064 & 1.473 & 0.978 & 2.221 \\
\hline & $\begin{array}{l}\text { Childhood trauma } \\
\text { experiences }\end{array}$ & 0.053 & 0.017 & 1.054 & 1.010 & 1.101 & 0.058 & 0.176 & 1.060 & 0.974 & 1.154 \\
\hline & Migration in times & 0.073 & 0.107 & 1.076 & 0.984 & 1.176 & -0.064 & 0.509 & 0.938 & 0.776 & 1.134 \\
\hline \multicolumn{12}{|c|}{ Note: $\mathrm{P}<0.05$ was considered statistically significant. } \\
\hline \multicolumn{12}{|c|}{ Unpleasant events in campus: 1 = Rarely, 2 = Occasionally, 3 = Sometimes, 4 = Plenty } \\
\hline \multicolumn{12}{|c|}{ Similar online activities in roommates: $1=$ No, $2=$ Yes } \\
\hline \multicolumn{12}{|c|}{ with a romantic relationship: $1=$ No, $2=$ Others } \\
\hline \multicolumn{12}{|c|}{ Infatuating with the internet before college: $1=$ No, $2=$ Yes } \\
\hline \multicolumn{12}{|c|}{ Father and/or mother deceased : $1=$ No, $2=$ Yes } \\
\hline \multicolumn{12}{|c|}{ Migration in times: $1=0,2=1,3=2,4=3$ and more } \\
\hline
\end{tabular}




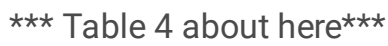

\section{Discussion}

In the present study, we found that more male than female students had moderate and severe IA. In the moderate and severe IA group, both male and female students tended to continuously use the internet for more than 5 hours once they started; the main online activity for the male students in the moderate and severe IA groups was online gaming, while for the female students in the moderate or severe IA groups, it was online streaming (e.g., watching movies and dramas). Boredom was the most prominent trigger for using internet-based entertainment; however, negative affect-triggered internet use was more likely to become moderate or severe IA. Infatuation with the internet before college and adjustment issues after entering college were shared risk factors for both gender groups in the mild and moderate IA groups. Roommates engaging in similar internet-based entertainment was a risk factor only for male students' IA and not being in a romantic relationship was only a risk factor for female students' IA. Relocation, the death of one or both parents, and childhood traumatic experience only affected mild IA.

\section{Type of internet use}

The main type of internet-based entertainment was different between male and female participants. Similar to previous research, our study found that online gaming is the main type of IA for male students [24]. For the female students in the moderate and severe IA group, $51.5 \%$ chose to use online streaming services as their main internet-based entertainment. This is possibly due to the relatively easy accessibility of online streaming services. It is also a risk factor for IA in female students, suggesting that research on female college students' IA should focus on this subtype. The different choice of internet-based entertainment between male and female students may be due to their unique needs and goals in using the internet.

\section{Duration of sustained online entertainment}

The duration of sustained online entertainment was used as an indicator of prolonged internet use for IA. It varied from 2 hours in the normal group to 5 hours in the moderate and severe IA groups. Previous studies usually use "how many hours per day" and "how many days per week" to assess the severity of IA [5, 6]. Wei and colleagues (2012) suggest that women tend to have shorter duration of sustained online entertainment, which is contradictory to our findings [24]. Our study found no statistically significant difference between gender groups, which suggests that it could potentially serve as a universal indicator of the severity of IA for both men and women.

\section{Triggers of internet-based entertainment}

Boredom, stress, and negative affect were common triggers of massive internet use $[25,26]$. Boredom was the main trigger of mild IA. Participants in the moderate and severe IA group reported a significantly higher incidence of negative affect-triggered internet use than boredom-triggered use. This suggests that online entertainment serves as a coping mechanism for individuals with moderate to severe IA. Female students rarely report invitation from friends as a trigger for online entertainment, while it is the second most reported trigger from male students.

\section{Risk factors for IA}

History of using the internet (infatuation with the internet) is considered a predictor of IA. Most individuals with internet game addiction reported having their first contact with online games in primary school and with internet overuse in middle school [7]; the time point of first contact might influence the severity of IA [24]. Our study yields a similar finding that experience with online games during early adolescence has an important impact on internet game addiction. Additionally, infatuation with the internet before college and adjustment issues at the beginning of college are common risk factors across gender groups.

IA could be a result of genes and environmental interactions. First-degree relatives of pathological gamblers showed significantly higher incidences of addictive behaviours compared to control groups [27] [28]. A twin study discovered that IA is 20 to 48 percent influenced by genetic factors [29] [30] and over 50 percent by environmental factors [30]. The current study found that infatuation with the internet before college and early encounters with the internet at a young age are prominent risk factors for IA. 
This suggests that genetic vulnerabilities combined with the influence of the family environment may play an important role in early contact with online entertainment and IA in childhood or adolescence.

\section{Clinical implication}

Since the current study found that boredom is a common trigger of internet use for the majority of college students, it is important to create interventions that target this problem. In China, high school students commonly spend an enormous amount of time preparing for college entrance exams. After the exam, students who were successfully admitted by colleges suddenly have much free time and wonder what is the source of their boredom. Facilitating and helping students engage in meaningful campus activities might help to reduce it. This further reduces the likelihood of students being addicted to the internet. Additionally, schools should pay close attention to the differences in triggering events between gender groups and design interventions accordingly.

Because online entertainment could potentially serve as a coping mechanism for negative affect, teaching students emotional regulation and stress management skills could be beneficial. Furthermore, preventions should be considered starting earlier, since early contact with the internet is associated with IA in college. Parents and teachers in elementary and middle schools should be prepared to be the first line of defence. Preventions could strive to put restrictions on the duration and type of online activities of children and internet use for adolescents.

\section{Limitations}

Since our study is conducted on college undergraduate students, the results may have the limitation of being generalizable to the broader population. Future research on this topic could include participants' genetic information and family environment (e.g., how parents use online entertainment or whether parents have any kind of addiction) on a more diverse population.

\section{Abbreviations}

ANOVA analysis of variance

IA internet addiction

IAT Internet Addiction Test

SES socioeconomic status

\section{Declarations}

Ethical approval and consent to participate The present study was approved by the Medical Ethics Committee of West China Hospital of Sichuan University. Online written informed consent was obtained from all participants.

Consent for publication Written informed consent for publication was obtained from all participants.

\section{Availability of data and materials Not applicable}

Competing Interests The authors declare that they have no conflict of interest.

Funding This work was supported by the Education Department of Sichuan Province, China (11SB142) played the role in the design of the study; the Department of Science and Technology of Sichuan provincial government (2019YFS0153) granted the data collection; the support of analysis came from the 1.3.5 Project for disciplines of excellence, West China Hospital of Sichuan University (ZY2016103, ZY2016203 and ZYGD20004), the interpretation of data in this study was funded by the Sichuan Provincial Health and Family Planning Commission, China (17PJ077) and the cooperation program of North Sichuan Medical College and Nanchong City China (18SXHZ0556) gave the assistance for the manuscript writing. 
Wan-jun Guo, Ya-jing Meng MD, Hui-yao Wang, Xiao-jing Li, Wei Deng, Lian-sheng Zhao, Xiao-hong Ma, Ming-li Li, Ting Chen, Andy S.K. Cheng analyzed and interpreted the data regarding the internet addiction. Jingyan Gu performed was a major contributor in writing the manuscript. All authors read and approved the final manuscript.

Acknowledgements We appreciated all individuals for providing some help for the manuscript.

\section{References}

1. Young, K.S., Internet Addiction: the emergence of a new clinical disorder. CyberPsychology \& Behavior, 1998. 1(3): $237-244$.

2. Shiffman, S. and S.L. Rathbun, Point process analyses of variations in smoking rate by setting, mood, gender, and dependence. Psychol Addict Behav, 2011. 25(3): 501-10.

3. Miyata, H., Reconsideration of nicotine and other substance dependence: a clue from dependence-related mentation including reward, motivation, learning, delusion and hallucination toward understanding the concept of non-substancerelated addiction. Nihon Shinkei Seishin Yakurigaku Zasshi, 2013. 33(5-6): 191-7.

4. Ding, W.N., et al., Altered default network resting-state functional connectivity in adolescents with Internet gaming addiction. Plos One, 2013. 8(3): e59902.

5. Morioka, H., et al., Association Between Smoking and Problematic Internet Use Among Japanese Adolescents: Large-Scale Nationwide Epidemiological Study. Cyberpsychol Behav Soc Netw, 2016. 19(9): 557-61.

6. Baggio, S., et al., Reframing video gaming and internet use addiction: empirical cross-national comparison of heavy use over time and addiction scales among young users. Addiction, 2016. 111(3): 513-22.

7. Li, W., et al., Characteristics of internet addiction/pathological internet use in U.S. university students: a qualitative-method investigation. PLoS One, 2015. 10(2): e0117372.

8. Tang, J., et al., Prevalence of internet addiction and its association with stressful life events and psychological symptoms among adolescent internet users. Addict Behav, 2014. 39(3): 744-7.

9. Meena, P.S., P.K. Mittal, and R.K. Solanki, Problematic use of social networking sites among urban school going teenagers. Ind Psychiatry J, 2012. 21(2): 94-7.

10. Gainsbury, S.M., et al., Who Pays to Play Freemium Games? The Profiles and Motivations of Players Who Make Purchases Within Social Casino Games. J Behav Addict, 2016. 5(2): 221-30.

11. Griffiths, M., A 'components' model of addiction within a biopsychosocial framework. Journal of Substance Use, 2009. 10(4): 191-197.

12. Lachmann, B., et al., Life satisfaction and problematic Internet use: Evidence for gender specific effects. Psychiatry Res, 2016. 238: 363-367.

13. Lee, C.S. and K. McKenzie, Socioeconomic and Geographic Inequalities of Internet Addiction in Korean Adolescents. Psychiatry Investig, 2015. 12(4): 559-62.

14. Santos, V., A.E. Nardi, and A.L. King, Treatment of internet addiction in patient with panic disorder and obsessive compulsive disorder: a case report. CNS Neurol Disord Drug Targets, 2015. 14(3): 341-4.

15. Xu, J., et al., Parent-adolescent interaction and risk of adolescent internet addiction: a population-based study in Shanghai. BMC Psychiatry, 2014. 14: 112.

16. Green, J.G., et al., Childhood adversities and adult psychiatric disorders in the national comorbidity survey replication I: associations with first onset of DSM-IV disorders. Arch Gen Psychiatry, 2010. 67(2): 113-23.

17. McLaughlin, K.A., et al., Childhood adversities and adult psychiatric disorders in the national comorbidity survey replication II: associations with persistence of DSM-IV disorders. Arch Gen Psychiatry, 2010. 67(2): 124-32.

18. Xiaoli Ni, et al., Factors Influencing Internet Addiction in a Sample of Freshmen University Students in China. CyberPsychology \& Behavior, 2009. 12(3): 327-330.

19. Poli, R. and E. Agrimi, Internet addiction disorder: prevalence in an Italian student population. Nord J Psychiatry, 2012. 66(1): 55-9. 
20. Young, K.S., Internet Addiction-A Handbook and Guide to Evaluation and Treatment. 2011.

21. Pontes, H.M., I.M. Patrao, and M.D. Griffiths, Portuguese validation of the Internet Addiction Test: An empirical study. J Behav Addict, 2014. 3(2): 107-14.

22. Lu, X. and K.J. Yeo, Psychometric properties of the Internet Addiction Test in a sample of Malaysian undergraduate students. Psicología Educativa, 2015. 21(1): 17-25.

23. Jian Qin, C., et al., Study on reliability and validity of Internet addiction impairment scale. Chinese general medicine, 2010(34): 3903-3905(In Chinese).

24. Wei, H.T., et al., The association between online gaming, social phobia, and depression: an internet survey. BMC Psychiatry, 2012. 12: 92.

25. Dong, G., et al., Precursor or sequela: pathological disorders in people with Internet addiction disorder. PLoS One, 2011. 6(2): e14703.

26. Wang, W.C., Exploring the Relationship Among Free-Time Management, Leisure Boredom, and Internet Addiction in Undergraduates in Taiwan. Psychol Rep, 2019. 122(5): 1651-1665.

27. Black, D.W., et al., A family study of pathological gambling. Psychiatry Res, 2006. 141(3): 295-303.

28. Black, D.W., et al., The relationship of DSM-IV pathological gambling to compulsive buying and other possible spectrum disorders: results from the lowa PG family study. Psychiatry Res, 2015. 226(1): 273-6.

29. Hahn, E., et al., Internet addiction and its facets: The role of genetics and the relation to self-directedness. Addict Behav, 2017. 65: 137-146.

30. Vink, J.M., Genetics of Addiction: Future Focus on Gene x Environment Interaction? J Stud Alcohol Drugs, 2016. 77(5): 684-7. 